\title{
The features of peritoneal metastases from gastric cancer
}

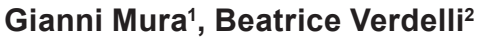 \\ IDepartment of Surgery, Valdarno Hospital, 52100 Arezzo, Italy. \\ ${ }^{2}$ Department of Radiology, Valdarno Hospital, 52100 Arezzo, Italy.
}

Correspondence to: Dr. Gianni Mura, Department of Surgery, Valdarno Hospital, Via Cimabue n.19, 52100 Arezzo, Italy.

E-mail: gianmura@gmail.com

How to cite this article: Mura G, Verdelli B. The features of peritoneal metastases from gastric cancer. J Cancer Metastasis Treat 2016;2:365-74.

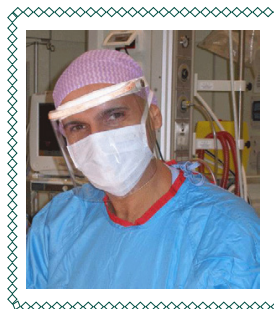

Dr. Gianni Mura is a Surgical Oncologist, General and Emergency Surgeon, and Gastro-intestinal Endoscopist. Since 1996 he focused his interest on surgical oncology, with experience in: loco-regional therapies for advancedstage abdominal cancers as the Early Post-operative Intraperitoneal Chemotherapy (EPIC) and the Hypoxic Chemo-perfusion (Stop-Flow); Cytoreductive Surgery and Hyperthermic Intraperitoneal Chemotherapy (HIPEC) for peritoneal carcinomatosis; Sentinel Node Biopsy for early gastric cancer; extended nodal dissection and neoadjuvant chemotherapy for advanced gastric cancer; surgery and adjuvant therapies for metastatic melanoma; clinical research.

Article history:

Received: 18-04-2016

Accepted: 19-07-2016

Published: 18-09-2016

Key words:

Gastric cancer, peritoneal carcinomatosis, hyperthermic intraperitoneal chemotherapy, immunotherapy, reverse transcription-polymerase chain reaction

\begin{abstract}
Peritoneal Carcinomatosis (PC) from metastasization of Gastric Cancer (GC), either present at first diagnosis of GC or as recurrence, is considered a fatal disease with no hope of definitive cure. Although newer agents like S1 and docetaxel have shown some promise, the median overall survival with the current first line chemotherapy is only 8 to 14 months, and is not greatly improved by adding targeted therapy. A multi-modal approach with cytoreductive surgery (CRS) associated with hyperthermic intraperitoneal chemotherapy (HIPEC) has been developed along the last two decades in order to tackle this problem. It's an aggressive, combined treatment still under investigation. Studies coming from Europe and Far East reported long-term survival with 5-year survival rates up to nearly $25 \%$ in case of complete cytoreduction. Prophylactic/adjuvant setting is the most evidence-based indication for HIPEC in advanced-stage GC patients without PC, in order to prevent peritoneal recurrence and to improve overall survival. The rationale for immuno treatment in patients with gastric PC is strong. A randomized phase II study, combining complete CRS with intraperitoneal catumaxomab is on-going. The detection of free peritoneal cancer cells is the more realistic and practical way for the identification of patients at risk of carcinomatosis after surgery. The routine use of techniques of molecular detection in peritoneal washing appears to be the more sensitive method. Such patients are potential candidate for multimodal and locoregional treatments in order to prevent the peritoneal recurrence.
\end{abstract}




\section{INTRODUCTION}

The regional metastatic spread of gastric cancer (GC) usually results in peritoneal carcinomatosis (PC). When GC patients are explored for potentially curative resection, $10-20 \%$ of them are found to have peritoneal metastases. ${ }^{[1]}$ Furthermore, in case of cancer infiltration of the serosal layer of the stomach, $\mathrm{PC}$ is present at first diagnosis of the cancer in $15-50 \%$ of cases and peritoneal recurrence develops in $35-60 \%$ of such patients after radical resection. PC is the only site of metastasis in $40-60 \%$ of patients. ${ }^{[2,3]}$ Therefore, peritoneal metastases alone usually result in death for $20-40 \%$ of patients with GC. ${ }^{[4]}$

Conventional surgery is not adequate for PC; current treatments are systemic chemotherapy and palliative therapy, with no hope of cure. In selected cases and in experienced centers, the association of more aggressive surgery with multimodal loco-regional treatments has shown to achieve prolonged survival and reduced peritoneal recurrences. ${ }^{[5-7]}$

\section{PHYSIO-PATHOLOGICAL FEATURES OF PC}

The molecular mechanisms by which GC undergoes $P C$ are not completely clear. Chemokines (CXC) are surely involved. They are small secretory proteins controlling migration and activation of leukocytes and other types of cell through interactions with a group of seven trans-membrane $G$ protein-coupled receptors. CXC may also promote growth/survival and metastasis of several malignancies. ${ }^{[8-11]}$ There is evidence that the axis between CXCL12 (highly expressed in peritoneum than in the liver or lymphnodes) and the receptor CXCR4 plays a role in the development of PC from GC. ${ }^{[12,13]}$ The CXCR4 antagonist AMD3100 prevents experimental PC by NUGC4 cells in nude mice. In human, the CXCR4 expression in primary tumors of patients with advanced GC significantly correlates with the occurrence of PC. Furthermore, CXCR4-expressing GC cells are preferentially attracted to the peritoneum cavity where its ligand CXCL12 is abundantly produced. The CXCL12/ CXCR4 axis is influenced by interaction with the vascular endothelial growth factor (VEGF). ${ }^{[14]}$ VEGF is markedly elevated in malignant ascites and is one of the essential elements in the development of PC. ${ }^{[12]}$ Such results suggest that the expression of CXCR4 in biopsy specimen from primary gastric tumors may be useful for preoperative evaluation of risks for the occurrence of PC. Evaluation of CXCL12 levels in intraoperative washing of abdominal cavity in patients with advanced GC has been proposed as a predictive molecular marker for the risk of PC.
Peritoneal dissemination of free cancer cells happens through exfoliation from the tumor and leads to direct invasion of the mesothelium. Surgery itself may produce intra-operative dissemination of cancer cells by severed lymphatics, intraperitoneal blood loss, trauma at narrow margins of resection etc.. According to the "tumor cell entrapment hypothesis" proposed by Sugarbaker $\mathrm{PH}$, immediately after a surgical procedure the endoperitoneal free cancer cells which are spontaneously exfoliated or iatrogenically disseminated adhere to the damaged surface created by surgery; they are trapped by fibrin and stimulated by growth factors of the wound healing and inflammation processes, with tumor cell implant on the visceral and parietal peritoneum. The nodule of carcinomatosis in this way becomes a hypoxic, and relatively immune to systemic chemotherapy, environment. ${ }^{[15]}$

Tumor cells can also diffuse through the "milky-spots", little cribriform "stomata" present on the peritoneal surface, communicating between peritoneal cavity and lymphatic vessels, with the function of re-absorption of abdominal fluids. Milky spots are mainly composed of macrophages and B1 cells; there are compelling data to consider the milky spots as unique secondary lymphoid organs. ${ }^{[16]}$ The peritoneal free cancer cells are trapped during their passage through the spots and attacked by inflammatory and immuno-response cells, forming a hypoxic nodule. ${ }^{[17]}$ The milky spots are mainly localized in the omentum and in the subdiaphragmatic areas, which are in fact the preferential sites of distribution of peritoneal metastases. ${ }^{[18]}$

\section{THE TREATMENT OF PC}

The PC arising from GC has ever been considered as a final stage of the disease, with no chances of cure but palliation. The prognosis of PC for GC is very poor, worse than that of other metastatic sites, ${ }^{[19,20]}$ with a median survival after diagnosis of only 3-7 months and 5 -year survival of $0 \% .^{[1,3]}$ The traditional approach by surgeons is just palliation, whenever possible.

\section{Systemic chemotherapy}

In last 15 years systemic chemotherapy (adjuvant or neoadjuvant) ${ }^{[21-26]}$ and adjuvant chemo-radiation ${ }^{[27,28]}$ do not have significantly lowered the rate of distant metastases, including peritoneal recurrence. In metastatic GC, systemic chemotherapy improves median survival to only 8-14 months, ${ }^{[29-31]}$ without great improving by adding targeted therapy. ${ }^{[32,33]} \mathrm{GC}$ patients with PC have a significantly reduced rate of tumor response to chemotherapy with reported rates of response of $14-25 \%{ }^{[34,35]}$ The poor response of $\mathrm{PC}$ to systemic chemotherapy is due to the presence 
of the "plasma-peritoneal barrier" which isolates the peritoneal cavity from the effects of intravenous chemotherapy. ${ }^{[36]}$ Although newer agents like S1 not available for Western Countries patients - and docetaxel have been reported to have better results against peritoneal metastases, yet the median survival even with these drugs is only 18 months. ${ }^{[37,38]}$

\section{Cytoreductive surgery and hyperthermic intraperitoneal chemotherapy}

A poor response to systemic therapy provides the rationale for a local-regional strategy for treatment. The concept is that carcinomatosis is not to be considered as systemic but compartment disease, which can be attacked by cytoreductive surgery (CRS) associated with loco-regional treatments such as the hyperthermic intraperitoneal chemotherapy (HIPEC). ${ }^{[5-7]}$ During CRS are used well-codified peritonectomy procedures with the removal of all visible cancer with the affected peritoneum through "peritoneal stripping", always attempting to achieve a complete cytoreduction [Figure 1]. ${ }^{[39]}$ The aim of CRS is the complete macroscopic cytoreduction as precondition for HIPEC. The residual disease is classified intra-operatively using the completeness of cytoreduction (CC) Score. The efficacy of intraperitoneal chemotherapy reaches its highest degree in absence of visible residual disease (CC-0) or in the presence of neoplastic residuals that are less or equal to $2.5 \mathrm{~mm}(\mathrm{CC}-1){ }^{[40,39]}$ The main theoretical advantage of intraperitoneal chemotherapy is that it allows the direct application of high local concentration of potentially effective drugs with minimal systemic exposure and toxicity. ${ }^{[2,5,7]}$

The neoplastic cells are more sensitive to the heat than the normal cells. Hyperthermia has a direct cytotoxic effect and an indirect effect by enhancing the action of several anti-neoplastic drugs. Experimental studies demonstrated that $42-43^{\circ} \mathrm{C}$ hyperthermia may have an important therapeutic effect on tumor tissue when applied alone; moreover hyperthermia synergically enhances the chemosensitivity of neoplastic cells to various antimitotic agents and allows deeper penetration of drugs into tumor tissue. ${ }^{[41,42]}$ During procedure of HIPEC, the chemotherapeutic agents are added into the extra-corporeal circuit as soon as the abdominal temperature reaches $41.5-42.5^{\circ} \mathrm{C}$ [Figure 2]. ${ }^{[40]}$

Postoperative mortality after CRS and HIPEC is 2-4\%, comparable to that following major gastrointestinal surgery. Morbidity is relatively high (25-41\%) and seems to be related to the extension of CRS rather than to the HIPEC itself. ${ }^{[43,6,7]}$ The anastomoses of total or subtotal gastrectomy in combination with CRS and

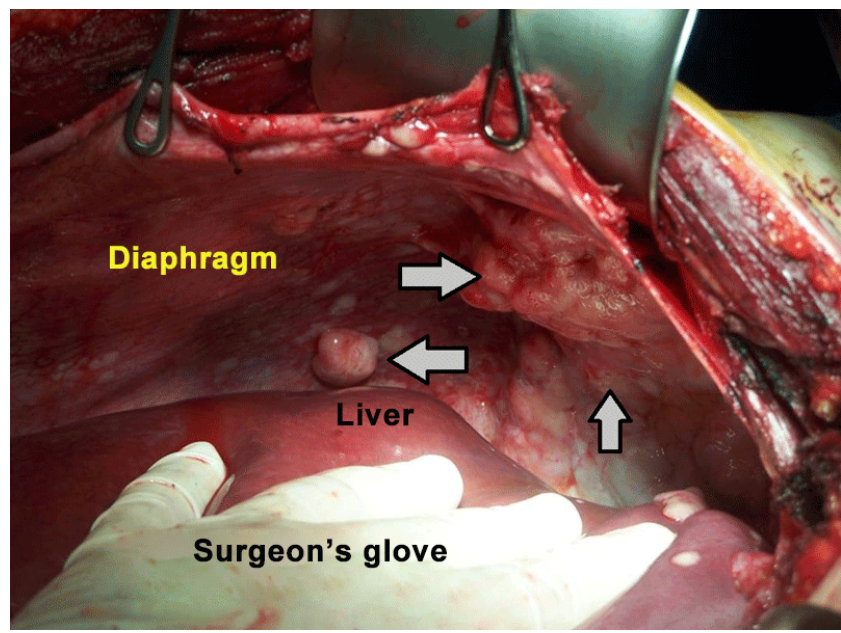

Figure 1: A phase of peritonectomy of diaphragmatic peritoneum; the arrows point to some nodules of carcinomatosis

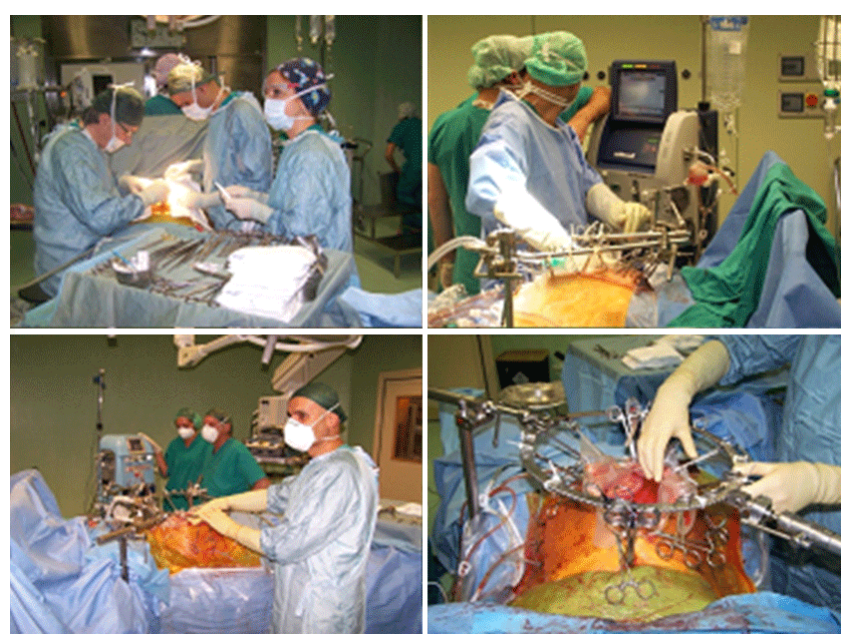

Figure 2: HIPEC procedures for gastric carcinomatosis. Two different models of surgical auto-retractors and two different HIPECdedicated devices are shown. HIPEC: hyperthermic intraoperative intraperitoneal chemotherapy

HIPEC are relatively safe. ${ }^{[44,45]}$

Currently, CRS with HIPEC is increasingly being used as a curative treatment of pseudomyxoma peritonei, peritoneal mesothelioma and selected patients with PC from colo-rectal or ovarian cancer. ${ }^{[46,5,7]}$ The CRS + HIPEC in PC arising from GC is a treatment still investigational. Several studies coming from Europe and Far East show the possibility of longterm survival with up to nearly $25 \% 5$-year survival rates in case of complete cytoreduction [Table 1]. Glehen et al. ${ }^{[54]}$ published in 2010 the results of a retrospective French study of 1,290 patients with PC treated with HIPEC; 159 of them had PC of gastric origin. In patients with a complete cytoreduction the $1-, 3-$, and 5-year survival rates were $61 \%, 30 \%$, and $23 \%$, respectively. Completeness of cytoreduction was the principal independent prognostic factor at multivariate analysis. ${ }^{[54,58]}$ In a systematic review of 
Table 1: Survival analysis in GC patients with PC treated with CRS and HIPEC

\begin{tabular}{|c|c|c|c|c|}
\hline Authors & Patients No. & $\begin{array}{l}\text { Agent used in } \\
\text { HIPEC }\end{array}$ & Mortality/morbidity (\%) & Survival \\
\hline Fujimoto et al. ${ }^{[47]}$ & 15 & MMC & - & $7.2 \pm 4.6 \mathrm{mo}$ \\
\hline Yonemura et al. ${ }^{[48]}$ & 41 & $\mathrm{MMC}+\mathrm{CDDP}$ & $0-29.3$ & 3 -year $28.5 \%$ \\
\hline Fujimoto et al. ${ }^{[49]}$ & 48 & MMC & - & 5 -year 31\%, 8-year $25.4 \%$ \\
\hline Hirose $^{[50]}$ & 17 & Etoposide & $5.8-35-2$ & $\begin{array}{c}\text { 1-year survival: HIPEC vs. control: } 44.4 \% \\
\text { vs. } 15.8 \%, P=0.04\end{array}$ \\
\hline Glehen et al. ${ }^{[44]}$ & 49 & MMC & $4-27$ & $\begin{array}{l}\text { 5-year survival (overall: } 16 \%, \text { CCO/1: } \\
\qquad 29.4 \% \text { ) }\end{array}$ \\
\hline Hall et al. ${ }^{[51]}$ & 34 & MMC & $0-35$ & 2 -year $45 \%,(\mathrm{CCO} / 1) 8 \%(\mathrm{CC} 2 / 3)$ \\
\hline Yonemura et al..$^{[52]}$ & 107 & $\mathrm{MMC}+\mathrm{CDDP}$ & $2.8-21.5$ & 5 -year $6.7 \%$ \\
\hline Scaringi et al. ${ }^{[53]}$ & 37 (26 with PC) & CDDP & $3.8-27$ & $\begin{array}{c}\text { median survival: CCR0 vs. CCR2- } 15 \mathrm{mo} \\
\text { vs. } 3.9 \mathrm{mo}, P=0.007\end{array}$ \\
\hline Glehen et al. ${ }^{[54]}$ & 139 & $\begin{array}{l}\mathrm{MMC} \pm \mathrm{CDDP} \text { or } \\
\mathrm{LOHP} \pm \text { irinotecan }\end{array}$ & $6.5-27.8$ & 5 -year $13 \%, \mathrm{CC} 0 / 123 \%$ \\
\hline Yang et $a l^{[55]}$ & $\begin{array}{l}\text { RCT: } 34 \text { vs. } 34 \text { no } \\
\text { HIPEC }\end{array}$ & $\mathrm{MMC}+\mathrm{CDDP}$ & $0-14.7$ & 3 -year $5.9 \%, \mathrm{CC} 0 / 123 \%$ \\
\hline Magge et al. ${ }^{[56]}$ & 23 & $\mathrm{MMC}+\mathrm{CDDP}$ & $4.3-52.2$ & 1 -year $50 \%$, 3-year $18 \%$ \\
\hline $\begin{array}{l}\text { Rudloff } \\
\text { GYMSSA trial }\end{array}$ & $\begin{array}{c}\text { RCT: } 9 \\
\text { CRS+HIPEC+cht vs. } 7 \\
\text { cht }\end{array}$ & Oxaliplatin & - & $\begin{array}{l}\text { Median OS } 11.3 \text { months in HIPEC arm } \\
\text { and } 4.3 \text { months in the cht arm. No patient } \\
\text { in the cht arm lived beyond } 11 \text { months }\end{array}$ \\
\hline
\end{tabular}

GC: Gastric cancer; CRS: cytoreductive surgery; HIPEC: hyperthermic intraoperative intraperitoneal chemotherapy; PC: peritoneal carcinomatosis; RCT: randomized controlled trial; MMC: mitomycin C; CDDP: cisplatin

10 published studies including 441 patients who underwent CRS and HIPEC in GC carcinomatosis, Gill et al. ${ }^{[43]}$ reported median overall survival of 7.9 months after HIPEC, increasing to 15 months in case of complete cytoreduction. The 5 -year survival of all patients was $13 \%$. Yang et al. ${ }^{[5]}$ showed in a phase III randomized clinical trial the importance of connecting CRS with HIPEC, in the treatment of PC of gastric cancer origin. The CRS-HIPEC association vs. CRS alone significantly increased median survival: $11 \mathrm{vs}$. 6.5 months. The prospective randomized clinical trial GYMSSA compared patients treated with CRSHIPEC and systemic chemotherapy vs. systemic chemotherapy treatment alone, demonstrating a benefit in terms of survival. With the limitation of a small number of patients, it showed a longer median overall survival (11.3 vs. 4.3 months) for CRS-HIPEC treatment trial arm. No patient in the systemicchemotherapy-alone arm lived beyond 12 months. ${ }^{[57]}$

Those are unexpected outcomes until some years ago indeed. Anyway, the results are worse than in case of other types of carcinomatosis treated with CRS and HIPEC ${ }^{[5,7]}$ The gastric is a more aggressive carcinomatosis, and complete cytoreduction is more difficult to achieve. The correct indication is probably the limited and resectable PC, where CC- 0 is achievable. ${ }^{[54]}$

\section{HIPEC in adjuvant setting}

Perhaps the most promising indication for HIPEC is its use in case of advanced GC without carcinomatosis in patients at risk of peritoneal recurrence. It's the adjuvant (or prophilactic) setting.

PC develops in $60 \%$ of patients with serosa-invading tumors after curative resection. ${ }^{[59,4]}$ In late ' 90 s some prospective RCTs evaluated adjuvant HIPEC after potentially curative GC resection. In Fujimoto's 141 patients, HIPEC significantly reduced the incidence of peritoneal recurrence $(P<0.001)$ and improved the survival rate $(P=0.03) .{ }^{[60]}$ Yonemura randomized 139 patients in three arms, surgery alone, surgery plus HIPEC, and intraperitoneal chemotherapy without hyperthermia. The 5 -year survival was $61 \%$ in the HIPEC group compared to $43 \%$ and $42 \%$ in the other two groups. ${ }^{[61]}$ Two meta-analysis of RCTs (including 1648 and 1062 patients, respectively) on HIPEC as adjuvant therapy in GC have been published. ${ }^{[62,63]}$ The patients, presenting GC with macroscopic serosal invasion but without distant metastases or PC, were randomly assigned to receive surgery combined 


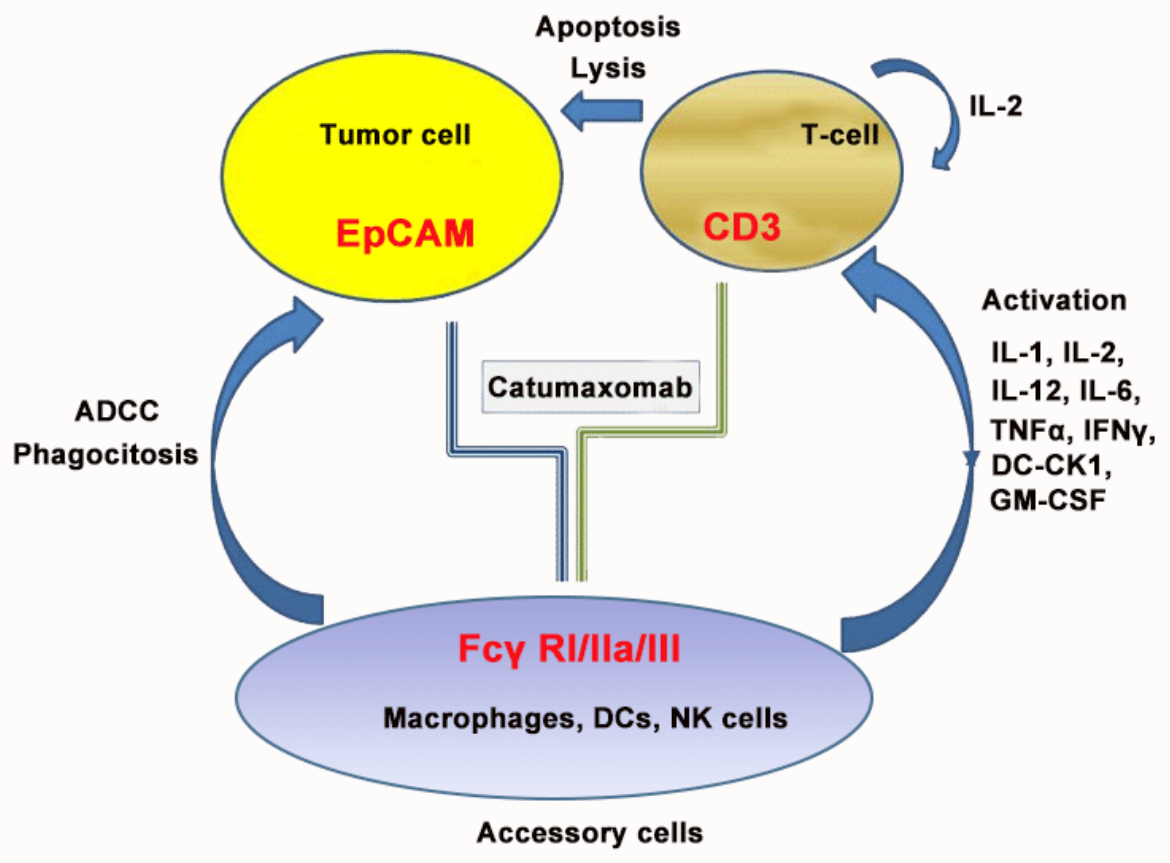

Figure 3: Catumaxomab, is a chimeric antibody, consisting in a mouse-derived anti-EpCAM Fab (fragment antigen-binding) region and a rat-derived anti CD3 Fab

with intraperitoneal chemotherapy or surgery without intraperitoneal chemotherapy. In both analyses a highly significant improvement in survival and in peritoneal recurrence rate was demonstrated for the HIPEC group compared to the control group. Recently, a metaanalysis on effects of intraperitoneal chemotherapy in advanced GC was reported by Coccolini et al. ${ }^{[64]}$ They imported the data from 20 prospective studies involving 2,145 patients. Overall suvival was increased when intraperitoneal chemotherapy was added to surgery; intraperitoneal chemotherapy was found to reduce the incidence of peritoneal recurrence and distant metastases. In the German S3-guidelines "Diagnosis and treatment of esophagogastric cancer" HIPEC as adjuvant treatment is reported with Level of Evidence I, grade A. ${ }^{[65]}$

Most of data anyway come from studies that have been conducted in Far-Eastern countries, with scarce contribute from the western world. Two RCTs about adjuvant HIPEC in GC patients are currently on-going in Europe. The "GASTRICHIP" is a phase III randomized multicentre study evaluating the role of HIPEC with oxaliplatin in patients with $\mathrm{GC}$ who have either serosal infiltration and/or lymph nodal involvement and/ or positive peritoneal cytology treated by a curative gastrectomy. ${ }^{[6]}$ Another trial is being conducted by the European network of excellence for gastric cancer. In this trial, patients with high risk GC will receive 3 cycles of neoadjuvant systemic chemotherapy followed by a D2 gastrectomy and then randomized to receive HIPEC or no HIPEC. ${ }^{[67]}$ Prophylactic/adjuvant setting is the more evidence-based indication for HIPEC in advanced-stage GC patients. No peritonectomy procedures are needed; post-operative morbidity and mortality are the same than surgery alone. Anyway a better and "standardized" identification of subset of patients at high risk of peritoneal recurrence is necessary. ${ }^{[68]}$

\section{Intraperitoneal immunotherapy}

Survival results for the treatment of PC from GC remain disappointing even with HIPEC, with 5-year survival rates of less than $25 \%$ in selected cases only. Innovative therapies such as intraperitoneal immunotherapy have been recently proposed.

The Chimera it's a legendary fire-breathing monster comprised of a lion, a goat, and a serpent. And chimera in genetics is a single animal organism with genetically distinct cells from two different zygotes. Chimera, or fusion protein, is called in biochemistry a hybrid protein made by the splicing of two genes. Catumaxomab is a chimeric antibody, consisting in a mouse-derived antiEpCAM Fab (fragment antigen-binding) region and a rat-derived anti CD3 Fab [Figure 3]. It is characterized by its ability to bind to three different types of cells: tumour cells expressing the epithelial cell adhesion molecule (EpCAM), T lymphocytes (CD3) and also accessory cells (Fcy receptor). In nearly $90 \%$ of GC 
the EpCAM antigen is expressed; on the contrary the peritoneal mesenchymal cells do not express it. ${ }^{[69]}$ The rationale is strong, more evidence on results is needed.

In a randomised study, a clinical effect was obtained after intraperitoneal infusion of catumaxomab in patients with symptomatic malignant ascites secondary to EpCAM+ carcinomas, 66 out of 258 notably from GC. ${ }^{[69]}$ Heiss and coll randomly assigned the patients to paracentesis alone, or to paracentesis plus intraperitoneal catumaxomab. Puncture-free survival was significantly longer in the group treated with catumaxomab compared to that in the control group (46 vs. 11 days, $P<0.0001$ ) but median overall survival was similar between the two groups: 72 days in the catumaxomab group vs. 68 days in the control group (n.s). ${ }^{[69]}$

Elias and his team from Gustave Roussy Institute (Villejuif, France), with long-date experience in HIPEC for $\mathrm{PC}$, recently proposed a randomized phase II study, combining complete cytoreductive surgery with intraperitoneal immunotherapy. ${ }^{[70]}$ The main inclusion criteria of the protocol are $\mathrm{PC}$ of minimum or moderate extension and macroscopic resection of all the lesions: they just match the experience-based indications for HIPEC in PC from GC. ${ }^{[54]}$ As requested for HIPEC, the complete resection of all macroscopic disease before starting the intra-peritoneal administration of catumaxomab is necessary. The immunotherapy could therefore efficiently treat microscopic residual disease.

\section{DIAGNOSIS OF INTRA-PERITONEAL FREE CANCER CELLS AND IDENTIFICATION OF PATIENTS AT RISK OF PERITONEAL RECURRENCE}

The methods of detecting peritoneal free cancer cells represent an area in evolution. It's well known that the positive peritoneal cytology is according to the depth in invasion of the gastric wall, and that it has a prognostic value..$^{[71,72]}$ In the same way, it's well known that cumulative risk of peritoneal recurrence is based on the infiltration of the gastric serosa. ${ }^{[73]}$ Cytological examination of peritoneal washing at the time of primary tumor resection is frequently positive. Free peritoneal cells are associated with an average survival of 4 months vs. 21 months for patients with negative cytology. ${ }^{[71,74]}$

According to the 7th edition of the American Joint Committee on Cancer positive cytology in the absence of visible peritoneal implants is considered as M1 disease. ${ }^{[75]}$ Peritoneal washing for cytology (better during a staging laparoscopy) is mandatory in staging/ treatment algorithm of advanced GC. ${ }^{[76]}$

The identification of patients at risk of peritoneal recurrence and the diagnosis of intra-peritoneal free cancer cells are probabilly two aspects of the same problem. The majority of patients with positive cytology on peritoneal washing develop PC, although it also may occur in patients with negative cytological results. These observations indicate that conventional cytology lacks sensitivity for the detection of residual cancer cells and the prediction of peritoneal spread. Many reports have emphasized the clinical significance of molecular diagnosis using reverse transcriptase-polymerase chain reaction analysis for more sensitive detection of GC cells in peritoneal washing. Fujiwara ${ }^{[77]}$ analyzed the survival of 123 patients with serosa-invading GC. The prognosis of the 29 patients with positive cytology in the peritoneal washing was very poor, and most of them died within 1 year after surgery. Among the 93 patients with negative cytology (CY0), 49 had a positive genetic diagnosis and a significantly poorer prognosis than those with negative genetic results. More than half of the patients with positive PCR and CYO developed peritoneal recurrence after surgery, while almost all patients with negative PCR and CY0 had no peritoneal recurrence after surgery. ${ }^{[7]}$ These results have been confirmed by many studies. All the authors concluded that molecular diagnosis based on peritoneal washing is useful to predict peritoneal recurrence for patients with serosal invasion of GC; PCR positivity has significant correlation with overall survival and with peritoneal recurrence rate..$^{[78-81]}$ Up 2 patients of 3 with negative cytology can be positive to PCR detection; in other terms, when surgeons perform R0 surgery (i.e. no macroscopic, microscopic and cytologic residual disease) for advanced GC, there is high probability that it's not true.

Molecular biological techniques are anyway time- and labour-intensive, and without yet diffuse application in clinical practice. A new rapid gene detection system, One-step nucleic acid amplification has been recently proposed. ${ }^{[82]}$ It shows potential for routine use in the clinical laboratory because of its simplicity and rapidity. On the other hand, the molecular detection of intraperitoneal GC cells is not only an independent prognostic factor, but also provides valuable clinical information for choosing the appropriate treatment for cytology-negative patients: such patients are potential candidate to intraperitoneal therapy, such as HIPEC, immunotherapy or both.

\section{CONCLUSION}

The peritoneal metastatic spread of GC leads to PC, a 
very aggressive disease with very poor prognosis. In selected GC patients with low peritoneal tumor burden, more aggressive multi-modal strategy with CRS plus intraperitoneal treatment as HIPEC may achieve longterm survival results with up to $25 \% 5$-year survival rates in case of complete cytoreduction. Moreover, there are strong evidences for HIPEC in adjuvant setting after radical surgery for preventing $P C$ in high risk GC patients. Intraperitoneal immunotherapy, when associated with radical surgery, may open very interesting perspectives for the future. The detection of free peritoneal cancer cells is the more realistic and practical way for the identification of patients at risk of carcinomatosis after surgery. The routine use of techniques of molecular detection in peritoneal washing appears to be the more sensitive method. Such patients are potential candidate for multimodal and locoregional treatments in order to prevent the peritoneal recurrence.

\section{Financial support and sponsorship} Nil.

\section{Conflicts of interest}

There are no conflicts of interest.

\section{Patient consent Obtained.}

\section{Ethics approval}

The patient was treated within the standards of authors' institute and the report was approved.

\section{REFERENCES}

1. Sadeghi B, Arvieux C, Glehen O, Beaujard AC, Rivoire M, Baulieux J, Fontaumard E, Brachet A, Caillot JL, Faure JL, Porcheron J, Peix JL, François Y, Vignal J, Gilly FN. Peritoneal carcinomatosis from nongynecologic malignancies: results of the EVOCAPE 1 multicentric prospective study. Cancer 2000;88:358-63.

2. Sugarbaker PH, Yonemura Y. Clinical pathway for the management of resectable gastric cancer with peritoneal seeding: best palliation with a ray of hope for cure. Oncology 2000;58:96-107.

3. Thomassen I, van Gestel YR, van Ramshorst B, Luyer MD, Bosscha K, Nienhuijs SW, Lemmens VE, de Hingh IH. Peritoneal carcinomatosis of gastric origin: a population-based study on incidence, survival and risk factors. Int J Cancer 2014;134:622-8.

4. Yonemura Y, Bandou E, Kinoshita K, Kawamura T, Takahashi S, Endou Y, Sasaki T. Effective therapy for peritoneal dissemination in gastric cancer. Surg Oncol Clin N Am 200312:635-48.

5. Neuwirth MG, Alexander HR, Karakousis GC. Then and now: cytoreductive surgery with hyperthermic intraperitoneal chemotherapy (HIPEC), a historical perspective. J Gastrointest Oncol 2016;7:18-28.

6. Yonemura Y, Bando E, Kawamura T, Ito H, Endo Y, Miura M, Kiyosaki K, Sasaki T. Cytoreduction and intraperitoneal chemotherapy for carcinomatosis from gastric cancer. Cancer Treat Res 2007;134:357-73.

7. Lungoci C, Mironiuc AI, Muntean V, Oniu T, Leebmann H, Mayr M, Piso P. Multimodality treatment strategies have changed prognosis of peritoneal metastases. World J Gastrointest Oncol 2016;8:67-82.

8. Strieter RM. Chemokines: not just leukocyte chemoattractants in the promotion of cancer. Nat Immunol 2001;2:285-6.

9. Geminder H, Sagi-Assif O, Goldberg L, Meshel T, Rechavi G, Witz IP, Ben-Baruch A. A possible role for CXCR4 and its ligand, the CXC chemokine stromal cell-derived factor- 1 , in the development of bone marrow metastases in neuroblastoma. J Immunol 2001;167:4747-57.

10. Jones D, Benjamin RJ, Shahsafaei A, Dorfman DM. The chemokine receptor CXCR3 is expressed in a subset of B-cell lymphomas and is a marker of B-cell chronic lymphocytic leukemia. Blood 2000;95:627-32.

11. Rempel SA, Dudas S, Ge S, Gutiérrez JA. Identification and localization of the cytokine SDF1 and its receptor, CXC chemokine receptor 4, to regions of necrosis and angiogenesis in human glioblastoma. Clin Cancer Res 2000;6:102-11.

12. Yasumoto K, Koizumi K, Kawashima A, Saitoh Y, Arita Y, Shinohara K, Minami T, Nakayama T, Sakurai H, Takahashi Y, Yoshie O, Saiki I. Role of the CXCL12/CXCR4 axis in peritoneal carcinomatosis of gastric cancer. Cancer Res 2006;66:2181-7.

13. Lee HJ, Jo DY. The role of the CXCR4/CXCL12 axis and its clinica implications in gastric cancer. Histol Histopathol 2012;27:1155-61.

14. Bachelder RE, Wendt MA, Mercurio AM. Vascular endothelial growth factor promotes breast carcinoma invasion in an autocrine manner by regulating the chemokine receptor CXCR4. Cancer Res 2002;62:7203-6.

15. Sugarbaker PH, Yu W, Yonemura Y. Gastrectomy, peritonectomy, and perioperative intraperitoneal chemotherapy: the evaluation of treatment strategies for advanced gastric cancer. Semin Surg Oncol 2003;21:233-48.

16. Mebius RE. Lymphoid organs for peritoneal cavity immune response: milky spots. Immunity 2009;30:670-2.

17. Miao ZF, Wang ZN, Zhao TT, Xu YY, Gao J, Miao F, Xu HM. Peritoneal milky spots serve as a hypoxic niche and favor gastric cancer stem/progenitor cell peritoneal dissemination through hypoxiainducible factor 1 $\alpha$. Stem Cells 2014;32:3062-74.

18. Yonemura Y, Endo Y, Yamaguchi T, Fujimura T, Obata T, Kawamura T, Nojima N, Miyazaki I, Sasaki T. Mechanisms of the formation of the peritoneal dissemination in gastric cancer. Int J Oncol 1996;8:795-802.

19. Chau I, Norman AR, Cunningham D, Waters JS, Oates J, Ross PJ. Multivariate prognostic factor analysis in locally advanced and metastatic esophago-gastric cancer -- pooled analysis from three multicenter, randomized, controlled trials using individual patient data. J Clin Oncol 2004;22:2395-403.

20. Kim JG, Ryoo BY, Park YH, Kim BS, Kim TY, Im YH, Kang YK. Prognostic factors for survival of patients with advanced gastric cancer treated with cisplatin-based chemotherapy. Cancer Chemother Pharmacol 2008;61:301-7.

21. Sakuramoto S, Sasako M, Yamaguchi T, Kinoshita T, Fujii M, Nashimoto A, Furukawa H, Nakajima T, Ohashi Y, Imamura H, Higashino M, Yamamura Y, Kurita A, Arai K; ACTS-GC Group. Adjuvant chemotherapy for gastric cancer with S-1, an oral fluoropyrimidine. N Engl J Med 2007;357:1810-20.

22. Bang YJ, Kim YW, Yang HK, Chung HC, Park YK, Lee KH, Lee KW, Kim YH, Noh SI, Cho JY, Mok YJ, Kim YH, Ji J, Yeh TS, Button P, Sirzén F, Noh SH; CLASSIC trial investigators. Adjuvant capecitabine and oxaliplatin for gastric cancer after D2 gastrectomy (CLASSIC): a phase 3 open-label, randomised controlled trial. Lancet 2012;379:315-21.

23. Cunningham D, Allum WH, Stenning SP, Thompson JN, Van de Velde CJ, Nicolson M, Scarffe JH, Lofts FJ, Falk SJ, Iveson TJ, Smith DB, Langley RE, Verma M, Weeden S, Chua YJ, MAGIC Trial Participants. Perioperative chemotherapy versus surgery alone for resectable gastroesophageal cancer. $N$ Engl J Med 2006;355:11-20. 
24. Ychou M, Boige V, Pignon JP, Conroy T, Bouché O, Lebreton G, Ducourtieux M, Bedenne L, Fabre JM, Saint-Aubert B, Genève J, Lasser P, Rougier P. Perioperative chemotherapy compared with surgery alone for resectable gastroesophageal adenocarcinoma: an FNCLCC and FFCD multicenter phase III trial. J Clin Oncol 2011;29:1715-21.

25. Xiong BH, Cheng Y, Ma L, Zhang CQ. An updated meta-analysis of randomized controlled trial assessing the effect of neoadjuvant chemotherapy in advanced gastric cancer. Cancer Invest 2014;32:2 72-84.

26. Cao J, Qi F, Liu T. Adjuvant chemotherapy after curative resection for gastric cancer: a meta-analysis. Scand J Gastroenterol 2014;49:690-704.

27. Smalley SR, Benedetti JK, Haller DG, Hundahl SA, Estes NC, Ajani JA, Gunderson LL, Goldman B, Martenson JA, Jessup JM, Stemmermann GN, Blanke CD, Macdonald JS. Updated analysis of SWOG-directed intergroup study 0116: a phase III trial of adjuvant radiochemotherapy versus observation after curative gastric cancer resection. J Clin Oncol 2012;30:2327-33.

28. Liang JW, Zheng ZC, Yu T, Wang X, Zhang JJ. Is postoperative adjuvant chemoradiotherapy efficacious and safe for gastric cancer patients with D2 lymphadenectomy? A meta-analysis of the literature. Eur J Surg Oncol 2014;40:1614-21.

29. Bilici A. Treatment options in patients with metastatic gastric cancer: current status and future perspectives. World J Gastroenterol 2014;20:3905-15.

30. Van Cutsem E, Moiseyenko VM, Tjulandin S, Majlis A, Constenla M, Boni C, Rodrigues A, Fodor M, Chao Y, Voznyi E, Risse ML, Ajani JA; V325 Study Group. Phase III study of docetaxel and cisplatin plus fluorouracil compared with cisplatin and fluorouracil as firstline therapy for advanced gastric cancer: a report of the V325 Study Group. J Clin Oncol 2006;24:4991-7.

31. Koizumi W, Narahara H, Hara T, Takagane A, Akiya T, Takagi M, Miyashita K, Nishizaki T, Kobayashi O, Takiyama W, Toh Y, Nagaie T, Takagi S, Yamamura Y, Yanaoka K, Orita H, Takeuchi M. S-1 plus cisplatin versus S-1 alone for first-line treatment of advanced gastric cancer (SPIRITS trial): a phase III trial. Lancet Oncol 2008;9:215-21.

32. Bang YJ, Van Cutsem E, Feyereislova A, Chung HC, Shen L, Sawaki A, Lordick F, Ohtsu A, Omuro Y, Satoh T, Aprile G, Kulikov E, Hill J, Lehle M, Rüschoff J, Kang YK; ToGA Trial Investigators. Trastuzumab in combination with chemotherapy versus chemotherapy alone for treatment of HER2-positive advanced gastric or gastro-oesophageal junction cancer (ToGA): a phase 3, open-label, randomised controlled trial. Lancet 2010;376:687-97.

33. Lordick F, Kang YK, Chung HC, Salman P, Oh SC, Bodoky G, Kurteva G, Volovat C, Moiseyenko VM, Gorbunova V, Park JO, Sawaki A, Celik I, Götte H, Melezínková H, Moehler M; Arbeitsgemeinschaft Internistische Onkologie and EXPAND Investigators. Capecitabine and cisplatin with or without cetuximab for patients with previously untreated advanced gastric cancer (EXPAND): a randomised, openlabel phase 3 trial. Lancet Oncol 2013;14:490-9.

34. Ross P, Nicolson M, Cunningham D, Valle J, Seymour M, Harper P, Price T, Anderson H, Iveson T, Hickish T, Lofts F, Norman A. Prospective randomized trial comparing mitomycin, cisplatin, and protracted venous-infusion fluorouracil (PVI 5-FU) With epirubicin, cisplatin, and PVI 5-FU in advanced esophagogastric cancer. J Clin Oncol 2002;20:1996-2004.

35. Baba H, Yamamoto M, Endo K, Ikeda Y, Toh Y, Kohnoe S, Okamura T. Clinical efficacy of S-1 combined with cisplatin for advanced gastric cancer. Gastric Cancer 2003;6 Suppl 1:45-9.

36. Jacquet P, Sugarbaker PH. Peritoneal-plasma barrier. Cancer Treat Res 1996;82:53-63.

37. Tamura S, Miki H, Okada K, Takeno A, Uji K, Yoshida A, Suzuki R, Nakahira S, Egawa C, Nakata K, Okamura S, Sugimoto K, Takatsuka Y. Pilot study of a combination of S-1 and paclitaxel for patients with peritoneal metastasis from gastric cancer. Gastric Cancer 2010;13:101-8.

38. Ishizone S, Maruta F, Saito H, Koide N, Sugiyama A, Nakayama J, Miyagawa S. Efficacy of S-1 for patients with peritoneal metastasis of gastric cancer. Chemotherapy 2006;52:301-7.

39. Sugarbaker PH. Peritonectomy procedures. Ann Surg 1995;221:29-42.

40. Mura G, Federici O, Garofalo A. Hyperthermic Intraperitoneal Chemotherapy in Gastric Cancer: Indications and Technical Notes. In: Iascone C, Paliotta A, Femia S, editors. Surgery in Multimodal Management of Gastric Cancer, Berlin: Springer-Verlag; 2012. p.107-12.

41. Giovanella BC, Stehlin JS Jr, Morgan AC. Selective lethal effect of supranormal temperature on human neoplastic cells. Cancer Res 1976;36:3944-50.

42. Wallner KE, Banda M, Li GC. Hyperthermic enhancement of cell killing by mitomycin $\mathrm{C}$ in mitomycin C-resistent Chinese hamster ovary cells. Cancer Res 1987;47:1308-12.

43. Gill RS, Al-Adra DP, Nagendran J, Campbell S, Shi X, Haase E, Schiller D. Treatment of gastric cancer with peritoneal carcinomatosis by cytoreductive surgery and HIPEC: a systematic review of survival, mortality, and morbidity. J Surg Oncol 2011;104:692-8.

44. Glehen O, Schreiber V, Cotte E, Sayag-Beaujard AC, Osinsky D, Freyer G, François Y, Vignal J, Gilly FN. Cytoreductive surgery and intraperitoneal chemohyperthermia for peritoneal carcinomatosis arising from gastric cancer. Arch Surg 2004;139:20-6.

45. Piso P, Slowik P, Popp F, Dahlke MH, Glockzin G, Schlitt HJ. Safety of gastric resections during cytoreductive surgery and hyperthermic intraperitoneal chemotherapy for peritoneal carcinomatosis. Ann Surg Oncol 2009; 16:2188-94.

46. Mura G, Framarini M, Vagliasindi A, Cavaliere D, Tauceri F, Solfrini G, Milandri C, Verdecchia GM. Preliminary experience with hyperthermic intraperitoneal chemo-perfusion with oxaliplatin for the treatment of peritoneal carcinomatosis due to colorectal carcinoma. Chir Ital 2007;59:217-23.

47. Fujimoto S, Shrestha RD, Kokubun M, Ohta M, Takahashi M, Kobayashi K, Kiuchi S, Okui K, Miyoshi T, Arimizu N. Intraperitoneal hyperthermic perfusion combined with surgery effective for gastric cancer patients with peritoneal seeding. Ann Surg 1988;208:36-41.

48. Yonemura Y, Fujimura T, Fushida S, Takegawa S, Kamata T, Katayama K, Kosaka T, Yamaguchi A, Miwa K, Miyazaki I. Hyperthermochemotherapy combined with cytoreductive surgery for treatment of gastric cancer with peritoneal dissemination. World $J$ Surg 1991;15:530-5.

49. Fujimoto S, Takahashi M, Mutou T, Kobayashi K, Toyosawa T, Isawa E, Sumida M, Ohkubo H. Improved mortality rate of gastric carcinoma patients with peritoneal carcinomatosis treated with intraperitoneal hyperthermic chemoperfusion combined with surgery. Cancer 1997;79:884-91.

50. Hirose K, Katayama K, Iida A, Yamaguchi A, Nakagawara G, Umeda S, Kusaka Y. Efficacy of continuous hyperthermic peritoneal perfusion for the prophylaxis and treatment of peritoneal metastasis of advanced gastric cancer: evaluation by multivariate regression analysis. Oncology 1999;57:106-14.

51. Hall JJ, Loggie BW, Shen P, Beamer S, Douglas Case L, McQuellon R, Geisinger KR, Levine EA. Cytoreductive surgery with intraperitoneal hyperthermic chemotherapy for advanced gastric cancer. J Gastrointest Surg 2004;8:454-63.

52. Yonemura Y, Kawamura T, Bandou E, Takahashi S, Sawa T, Matsuki $\mathrm{N}$. Treatment of peritoneal dissemination from gastric cancer by peritonectomy and chemohyperthermic peritoneal perfusion. $\mathrm{Br} J$ Surg 2005;92:370-5.

53. Scaringi S, Kianmanesh R, Sabate JM, Facchiano E, Jouet P, Coffin B, Parmentier G, Hay JM, Flamant Y, Msika S. Advanced gastric cancer with or without peritoneal carcinomatosis treated with hyperthermic 
intraperitoneal chemotherapy: a single western center experience. Eur J Surg Oncol 2008;34:1246-52.

54. Glehen O, Gilly FN, Arvieux C, Cotte E, Boutitie F, Mansvelt B, Bereder JM, Lorimier G, Quenet F, Elias D; Association Française de Chirurgie. Peritoneal carcinomatosis from gastric cancer: a multiinstitutional study of 159 patients treated by cytoreductive surgery combined with perioperative intraperitoneal chemotherapy. Ann Surg Oncol 2010;17:2370-7.

55. Yang XJ, Huang CQ, Suo T, Mei LJ, Yang GL, Cheng FL, Zhou YF, Xiong B, Yonemura Y, Li Y. Cytoreductive surgery and hyperthermic intraperitoneal chemotherapy improves survival of patients with peritoneal carcinomatosis from gastric cancer: final results of a phase III randomized clinical trial. Ann Surg Oncol 2011;18:1575-81.

56. Magge D, Zenati M, Mavanur A, Winer J, Ramalingam L, Jones H, Zureikat A, Holtzman M, Lee K, Ahrendt S, Pingpank J, Zeh HJ, Bartlett DL, Choudry HA. Aggressive locoregional surgical therapy for gastric peritoneal carcinomatosis. Ann Surg Oncol 2014;21:1448-55.

57. Rudloff U, Langan RC, Mullinax JE, Beane JD, Steinberg SM, Beresnev T, Webb CC, Walker M, Toomey MA, Schrump D, Pandalai P, Stojadinovic A, Avital I. Impact of maximal cytoreductive surgery plus regional heated intraperitoneal chemotherapy (HIPEC) on outcome of patients with peritoneal carcinomatosis of gastric origin: results of the GYMSSA trial. J Surg Oncol 2014;110:275-84.

58. Glehen O, Gilly FN, Boutitie F, Bereder JM, Quenet F, Sideris L, Mansvelt B, Lorimier G, Msika S, Elias D; French Surgical Association. Toward curative treatment of peritoneal carcinomatosis from nonovarian origin by cytoreductive surgery combined with perioperative intraperitoneal chemotherapy: a multi-institutional study of 1,290 patients. Cancer 2010;116:5608-18.

59. Al-Shammaa HA, Li Y, Yonemura Y. Current status and future strategies of cytoreductive surgery plus intraperitoneal hyperthermic chemotherapy for peritoneal carcinomatosis. World $J$ Gastroenterol 2008;14:1159-66.

60. Fujimoto S, Takahashi M, Mutou T, Kobayashi K, Toyosawa T. Successful intraperitoneal hyperthermic chemoperfusion for the prevention of postoperative peritoneal recurrence in patients with advanced gastric carcinoma. Cancer 1999;85:529-34.

61. Yonemura Y, de Aretxabala X, Fujimura T, Fushida S, Katayama K, Bandou E, Sugiyama K, Kawamura T, Kinoshita K, Endou Y, Sasaki T. Intraoperative chemohyperthermic peritoneal perfusion as an adjuvant to gastric cancer: final results of a randomized controlled study. Hepatogastroenterology 2001;48:1776-82.

62. Yan TD, Black D, Sugarbaker PH, Zhu J, Yonemura Y, Petrou G, Morris DL. A systematic review and meta-analysis of the randomized controlled trials on adjuvant intraperitoneal chemotherapy for resectable gastric cancer. Ann Surg Oncol 2007;14:2702-13.

63. Sun J, Song Y, Wang Z, Gao P, Chen X, Xu Y, Liang J, Xu H. Benefits of hyperthermic intraperitoneal chemotherapy for patients with serosal invasion in gastric cancer: a meta-analysis of the randomized controlled trials. BMC Cancer 2012;12:526.

64. Coccolini F, Cotte E, Glehen O, Lotti M, Poiasina E, Catena F, Yonemura Y, Ansaloni L. Intraperitoneal chemotherapy in advanced gastric cancer. Meta-analysis of randomized trials. Eur J Surg Oncol 2014;40:12-26.

65. Moehler M, Al-Batran SE, Andus T, Anthuber M, Arends J, Arnold D, Aust D, Baier P, Baretton G, Bernhardt J, Boeing H, Böhle E, Bokemeyer C, Bornschein J, Budach W, Burmester E, Caca K, Diemer WA, Dietrich CF, Ebert M, Eickhoff A, Ell C, Fahlke J, Feussner H, Fietkau R, Fischbach W, Fleig W, Flentje M, Gabbert HE, Galle PR, Geissler M, Gockel I, Graeven U, Grenacher L, Gross S, Hartmann JT, Heike M, Heinemann V, Herbst B, Herrmann T, Höcht S, Hofheinz RD, Höfler H, Höhler T, Hölscher AH, Horneber M, Hübner J, Izbicki JR, Jakobs R, Jenssen C, Kanzler S, Keller M, Kiesslich R, Klautke
G, Körber J, Krause BJ, Kuhn C, Kullmann F, Lang H, Link H, Lordick F, Ludwig K, Lutz M, Mahlberg R, Malfertheiner P, Merkel S, Messmann H, Meyer HJ, Mönig S, Piso P, Pistorius S, Porschen R, Rabenstein T, Reichardt P, Ridwelski K, Röcken C, Roetzer I, Rohr P, Schepp W, Schlag PM, Schmid RM, Schmidberger H, Schmiegel WH, Schmoll HJ, Schuch G, Schuhmacher C, Schütte K, Schwenk W, Selgrad M, Sendler A, Seraphin J, Seufferlein T, Stahl M, Stein H, Stoll C, Stuschke M, Tannapfel A, Tholen R, Thuss-Patience P, Treml K, Vanhoefer U, Vieth M, Vogelsang H, Wagner D, Wedding U, Weimann A, Wilke H, Wittekind C; AWMF; AWMF. German S3guideline "Diagnosis and treatment of esophagogastric cancer". Z Gastroenterol 2011;49:461-531.

66. Glehen O, Passot G, Villeneuve L, Vaudoyer D, Bin-Dorel S, Boschetti G, Piaton E, Garofalo A. GASTRICHIP: D2 resection and hyperthermic intraperitoneal chemotherapy in locally advanced gastric carcinoma: a randomized and multicenter phase III study. BMC Cancer 2014;14:183.

67. Roviello F, Caruso S, Neri A, Marrelli D. Treatment and prevention of peritoneal carcinomatosis from gastric cancer by cytoreductive surgery and hyperthermic intraperitoneal chemotherapy: overview and rationale. Eur J Surg Oncol 2013;39:1309-16.

68. Canbay E, Yonemura Y, Brucher B, Baik SH, Sugarbaker PH. Intraperitoneal chemotherapy and its evolving role in management of gastric cancer with peritoneal metastases. Chin J Cancer Res $2014 ; 26: 1-3$.

69. Heiss MM, Murawa P, Koralewski P, Kutarska E, Kolesnik OO, Ivanchenko VV, Dudnichenko AS, Aleknaviciene B, Razbadauskas A, Gore M, Ganea-Motan E, Ciuleanu T, Wimberger P, Schmittel A, Schmalfeldt B, Burges A, Bokemeyer C, Lindhofer H, Lahr A, Parsons SL. The trifunctional antibody catumaxomab for the treatment of malignant ascites due to epithelial cancer: Results of a prospective randomized phase II/III trial. Int J Cancer 2010;127:2209-21.

70. Goéré D, Gras-Chaput N, Aupérin A, Flament C, Mariette C, Glehen O, Zitvogel L, Elias D. Treatment of gastric peritoneal carcinomatosis by combining complete surgical resection of lesions and intraperitoneal immunotherapy using catumaxomab. BMC Cancer 2014;14:148.

71. Bando E, Yonemura Y, Takeshita Y, Taniguchi K, Yasui T, Yoshimitsu Y, Fushida S, Fujimura T, Nishimura G, Miwa K. Intraoperative lavage for cytological examination in 1,297 patients with gastric carcinoma. Am J Surg 1999;178:256-62.

72. Makino T, Fujiwara Y, Takiguchi S, Miyata H, Yamasaki M, Nakajima K, Nishida T, Mori M, Doki Y. The utility of pre-operative peritoneal lavage examination in serosa-invading gastric cancer patients. Surgery 2010;148:96-102.

73. Roviello F, Marrelli D, de Manzoni G, Morgagni P, Di Leo A, Saragoni L, De Stefano A; Italian Research Group for Gastric Cancer. A prospective study of peritoneal recurrence after curative surgery for gastric cancer. Br J Surg 2003;90:1113-9.

74. Bonenkamp JJ, Songun I, Hermans J, van de Velde CJ. Prognostic value of positive cytology findings from abdominal washings in patients with gastric cancer. Br J Surg 1996;83:672-4.

75. Edge S. Cancer AJCo: AJCC cancer staging manual. 7th ed. New York: Springer, 2010.

76. Allum WH, Blazeby JM, Griffin SM, Cunningham D, Jankowski JA, Wong R. Association of Upper Gastrointestinal Surgeons of Great Britain and Ireland, the British Society of Gastroenterology and the British Association of Surgical Oncology. Guidelines for the management of oesophageal and gastric cancer. Gut 2011;60:1449-72.

77. Fujiwara Y, Doki Y, Taniguchi H, Sohma I, Takiguchi S, Miyata H, Yamasaki M, Monden M. Genetic detection of free cancer cells in the peritoneal cavity of the patient with gastric cancer: present status and future perspectives. Gastric Cancer 2007;10:197-204.

78. Katsuragi K, Yashiro M, Sawada T, Osaka H, Ohira M, Hirakawa K. 
Prognostic impact of PCR-based identification of isolated tumor cells in the peritoneal lavage fluid of gastric cancer patients who underwent a curative R0 resection. Br J Cancer 2007;97:550-6.

79. Wong J, Kelly KJ, Mittra A, Gonen M, Allen P, Fong Y, Coit D. RtPCR increases detection of submicroscopic peritoneal metastases in gastric cancer and has prognostic significance. J Gastrointest Surg 2012;16:889-96.

80. Takata A, Kurokawa Y, Fujiwara Y, Nakamura Y, Takahashi T, Yamasaki M, Miyata H, Nakajima K, Takiguchi S, Mori M, Doki Y. Prognostic value of CEA and CK20 mRNA in the peritoneal lavage fluid of patients undergoing curative surgery for gastric cancer. World
J Surg 2014;38:1107-11

81. Takebayashi K, Murata S, Yamamoto H, Ishida M, Yamaguchi T, Kojima M, Shimizu T, Shiomi H, Sonoda H, Naka S, Mekata E, Okabe H, Tani T. Surgery-induced peritoneal cancer cells in patients who have undergone curative gastrectomy for gastric cancer. Ann Surg Oncol 2014;21:1991-7.

82. Nakabayashi K, Uraoka T, Shibuya M, Matsuura N, Tsujimoto M Rapid detection of CEA mRNA in peritoneal washes using One-Step Nucleic acid Amplification (OSNA) for gastric cancer patients. Clin Chim Acta 2015;439:137-42. 